\title{
THE INFLUENCE OF INTERNAL ENVIRONMENTAL FACTORS ON THE FUNCTIONING OF THE ENTERPRISE AND ON THE EFFICIENCY OF MANAGEMENT DECISION-MAKING
}

\author{
ВПЛИВ ФАКТОРІВ ВНУТРІШНЬОГО СЕРЕДОВИЩА \\ НА ФУНКЦІОНУВАННЯ ПІДПРИЕМСТВОМ \\ ТА НА ЕФЕКТИВНІСТЬ ПРИЙНЯТТЯ УПРАВЛІНСЬКИХ РІШЕНЬ
}

UDC 657.631

DOI: https://doi.org/10.32843/infrastruct47-12

\section{Brychko Alina}

Ph.D. in Economics,

Associate Professor at Department of

Public Management and Administration

Sumy National Agrarian University

Kovalenko Zoia

Student

Sumy National Agrarian University
The article analyzes the internal factors aimed at identifying the advantages and disadvantages of the enterprise, ranking them according to the degree of importance for immediate response in the interests of the enterprise, as well as mobilization to implement the chosen alternative. The internal environment of an organization is a set of components that are interconnected through certain structures within the organization. The main variables of the internal environment of the organization include: goals, objectives, structures, technologies, people. They directly affect management decisions and the successful existence of the organization. That is why we decided to investigate this issue in more depth. To form a solution, the criteria for its effectiveness must be defined. In the article you can learn about the main and most important factors of the internal environment that affect the success of the enterprise and management decisions, their relationship and ways to solve problems.

Key words: internal environment, analysis, organization, personnel, technologies, production

В статье осуществлен анализ внутренних фракторов, направленный на выявление преимуществ и недостатков в работе предприятия, ранжирование их по степени важности для немедленного реагирования в интересах предприятия, а также мобилизацию на выполнение выбранной альтернативы действий. Внутренняя среда организации - это совокупность компонентов, связанных между собой с помощью определенных структур в рамках органи зации. К основным переменных внутренней среды организации относятся: чели, задачи структуры, технологии, люди. Они непосредственно влияют на принятие управленческих решений и на успешное существование организации. Именно поэтому мы решили исследовать этот вопрос более углубленно. Для формирования решения должны быть определены критерии его эфорективности. В статье вы можете узнать о главных и нашболее важных фракторах внутренней среды, которые влияют на успешность предприятия и на принятие управленческих решений; их взаимосвязь и пути решения проблем.

Ключевые слова: внутренняя среда, анализ, организация, кадры, технологии, производство.

У статті здійснено аналіз внутрішніх факторів, що спрямований на виявлення переваг і недоліків у роботі підприємства, ранжування їх за ступенем важливості для негайного реагування в інтересах підприємства, а також мобілізацію на виконання обраної альтернативи дій. Внутрішнє середовище організації - це сукупність компонентів, пов'язаних між собою за допомогою певних структур у межах організації. До основних змінних внутрішнього середовища організації належать: цілі, завдання, структура, технології, люди. Вони безпосередньо впливають на прийняття управлінських рішень та на успішне існування організації. Саме тому вирішено досліджувати че питання більш поглиблено. Для фрормування рішення повинні бути визначені критерії його ефективності. Вони необхідні при зіставленні різних варіантів рішень і вибору найкращого з них, а також для оцінки міри досягнення поставленої мети. Критерій оцінки ефективності рішень повинен мати кількісне вираження, найбільш повно відображати результати рішень, бути простим і конкретним. Правильний вибір критерію ефективності, на думку фахівців, еквівалентний правильному фрормулюванню задачі, оскільки нерідко сам критерій сприяє визначенню напрямів рішення задачі. Успішно прийняте рішення грунтується на здібностях і мотивації оптимального ухвалення рішення: якість прийняття рішень є результатом злиття знань у відповідній ссрері прийняття рішень, комунікаційних здібностей, мотивації і здібностей переконати іншого у власних ідеях, здібностей проведення необхідних етапів раціонального ухвалення рішення, а також уміння достовірно оцінити передбачувані та фрактично отримані наслідки. У статті ви можете дізнатись про головні та найбільш важливі фактори внутрішнього середовища, що впливають на успішність підприємства та на прийняття управлінських рішень; їх взаємозв'язок та шляхи вирішення проблем. Доведено, що фрактори впливу внутрішнього середовища підприємства на ефеективність прийняття управлінського рішення являють собою сукупність усіх внутрішніх змінних, які визначають процеси діяльності підприємства та визначають його потенціал, що може бути реалізований при наданні комплексу послуг.

Ключові слова: внутрішнє середовище, аналіз, організація, кадри, технології, виробництво.

Problem statement. Modern concepts of management consider the organization as an open system. Through transparency, such an organization adapts to changes in the external environment and responds to changing opportunities, forecasts and challenges of this environment. The organization cannot ignore the transformation in the internal environment and hope for successful operation in the long run.

It is possible to state the absence of a system of factors of internal influence, able to fully characterize the conditions and parameters of the existence of the internal environment of the enterprise and the internal efficiency of the enterprise management.
Therefore, the question of establishing directions for grouping factors of internal influence on the efficiency of the enterprise management becomes relevant. The formation of factors should be carried out taking into account the existing research results and current trends inherent in the enterprise, among which it is appropriate to note the following: economic condition, organizational structure, technical capacity, innovation and eco-destructive impact on the environment.

Analysis of recent research. The internal environment of the enterprise is a set of internal factors that directly affect functioning of the enterprise. Different authors propose various approaches to the 
formation of groups of factors of the internal environment. So, O.S. Vikhanskiy and A.I. Naumov [9] identifies five main groups of internal environmental factors that correspond to the main directions of the management system. This formation of factors is undoubtedly meaningful, appropriate and will allow further assessment of the influence of factors. However, the study of Rumiantseva Z.P. [8] substantiate the feasibility of determining when conducting a factor analysis of the effectiveness of enterprise management - organizational or corporate culture.

The aim of the study. The main purpose of the article is to study and analyze internal factors, aimed at identifying the advantages and disadvantages of the enterprise, ranking them in order of importance for immediate response in the interests of the enterprise, as well as mobilization to implement selected alternative actions for effective management decisions.

Material and research methods. In the domestic and foreign literature, the factors of influence of the environment on the activity of enterprises are thoroughly analyzed, the possible consequences of such influence are determined, but the influence of the factors of the internal environment on the strategic management of the enterprise is not fully studied. In particular, the classification of internal factors influencing the functioning of the enterprise is covered in the works of the following scientists: R.S. Soroka [1, p. 76], H.O. Rohanova [2], S.Yu. Kulakova, D.M. Lozovskyi [3], N.I. Hordienko [4, p. 83], Z.Ye.Shershnova, S.V. Oborska[5, p. 38], D.O. Horielov, S.F. Bolshenko [6, p. 25], Ye.O. Minina [7, p. 225]. The results of the analysis of scientific works characterize the presence of a small number of studies, the lack of a single point of view on the nature and definition of the influence of internal factors on management decisions in the enterprise. All of the above determines the relevance of the chosen research topic.

Research results. The problem of determining the effectiveness of enterprise management and finding ways of improvement is complex. After all, any enterprise is an open system that operates within the influence of many factors. Thus, a number of factors create certain opportunities, the timely use of which will increase the efficiency of enterprise management. Some factors, on the contrary, pose a threat to the existence of the enterprise. Minimizing such threats is a top priority for effective management. That is why it is advisable to study the factors influencing the effectiveness of the enterprise management.

Of course, a successful decision is based on the ability and motivation for optimal decision-making: the quality of decision-making is the result of merging knowledge in the relevant field of decision-making, communication skills, motivation and ability to convince others of their own ideas, ability to assess the expected and actual consequences reliably.
The effectiveness and quality of management decisions depends on many factors. The main ones are the problem solving methodologies, which are the principles, methods and scientific approaches that are presented in Figure 1.

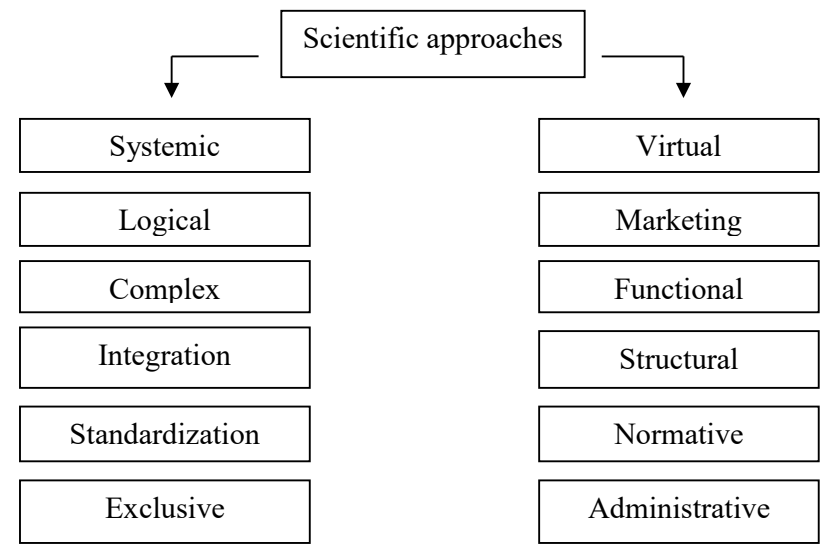

Figure 1. Scientific approaches to solving management problems

Source: developed by the authors according to [9]

There are many scientific approaches; each of them is better suited to a particular organization, form of government. In our opinion, a complex approach will help to deepen the problem, take into account all aspects of management for the best solution.

A complex approach is one of the types of system approach, which is the unity of ideological and political, labor, moral, physical and aesthetic education and provides comprehensive development, improving the efficiency of education, the function of optimizing the educational process.

A complex approach involves the simultaneous development of technical, environmental, economic, organizational, psychological and other aspects of management in their relationship (Figure 2).

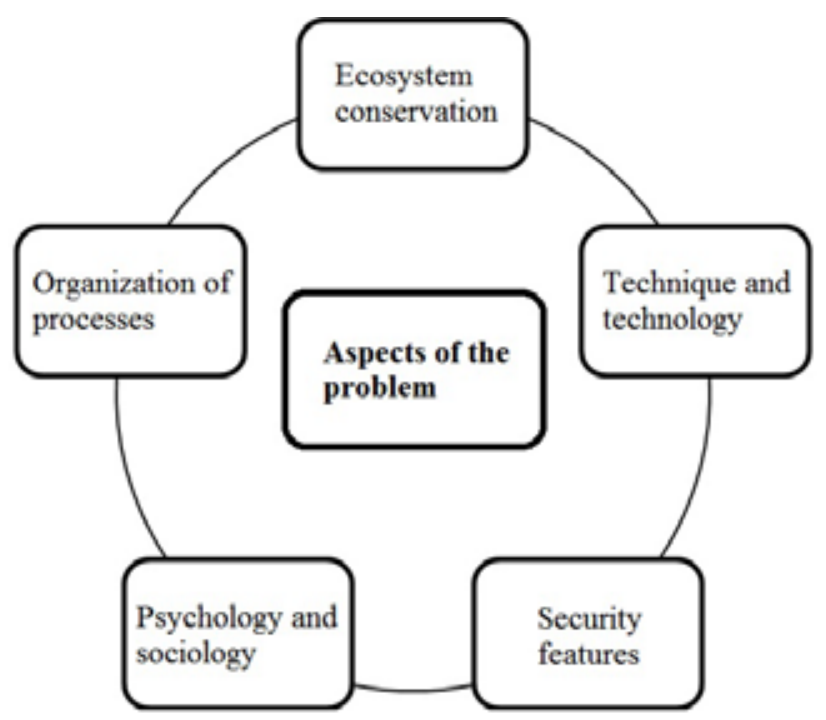

Figure 2. Aspects of a complex approach

Source: developed by the authors according to [8] 
Depending on the strength of the factors of each environment, one of them is dominant over the other and affects its functioning.

The effectiveness of management largely depends on the influence of internal and external factors that interact with each other. That is why there is a need for a detailed study of the determinants of enterprise management.

The analysis of the influence on the efficiency of the enterprise management is expedient to carry out from two points of view:

- firstly, it is the influence of the external environment, which can include macro- and microenvironment of the enterprise. In some literature sources [6], [9] the external environment is divided into factors of the general environment (factors of indirect influence) and the operational environment (factors of direct influence). However, to study the factors influencing the external environment, it is necessary to use a methodology that will take into account the existing problems of the state, economic, technological and innovative nature and the versatility of the enterprise. That is why it will be advisable to structure the factors of the external environment at the macro level according to the method of T.E.M.P.L.E.S. (Technology, Economics, Market, Politics, Laws, Ecology, Society). Its advantage is that it covers a significant amount of environmental factors in a structured form.

- secondly, it is the internal environment, which is about the factors of the enterprise itself, consisting of the processes of ensuring the activities and management, which we will consider in more detail.

The study of factors of internal influence on the activities of the enterprise includes a number of works, much of which relates to the definition of the classification of determinants.

So, O.S. Vikhanskiy classified the factors of the internal environment as follows: the state of the industry and the position of the enterprise in the industry; enterprise goals; interests and attitudes of management; financial resources; qualification of workers; liabilities of the enterprise; degree of dependence on the external environment; time factor; the size of the enterprise [9]. R. Fatkhutdinov identified the factors of the internal environment, through which the company can achieve competitive advantage: structural, resource, technical, managerial, market, the efficiency of the organization [10]. The diversity in the classifications of factors indicates the diversity of the internal environment and the possibility of introducing groups of factors that fit the subject of study best. Thus, the factors influencing the internal environment of the enterprise on the effectiveness of management decisions are a set of all internal variables that determine the processes of the enterprise and determine its potential that can be realized in the provision of services. That is why among the factors of internal influence we distinguish the following: production, economic, environmental, innovative, organizational and structural.

The production factor that affects the level of management efficiency includes a number of determinants, characterizing the main production capacity of the enterprise, namely, the level of moral and physical wear of equipment, production capacity of existing equipment, primary energy resources, reserve capacity and existing quality control. The production factor is the most important among a number of existing factors, because the economic result, environmental damage depends on the quantity and quality of products or services provided by the enterprise.

It should be noted that the weight influence on the level of efficiency of the enterprise management is carried out by the innovation factor, among which the following can be distinguished: innovations in management, production, personnel.

Innovations in management and personnel should be understood as the use of new methods of stimulation, motivation, forecasting, planning, training, which will significantly increase the efficiency of management by improving the quality characteristics of the management staff.

Innovations in the production of the enterprise do not have the form of fundamental innovations. However, the use of the latest tools in the repair, accounting, consumer information, the use of innovative insulating materials, filtration systems have a positive impact on the level of management efficiency.

Unconditional influence on the efficiency of enterprise management is exerted by the organizational and structural factor. This is characterized by the level of staff skills, the overall development strategy of the enterprise, the intellectual potential of the enterprise, productivity, organizational structure and management methods. Organizational and structural factor affects the effectiveness of management through:

- effectiveness of the management process;

- efficiency of management structure;

- quality of key management personnel.

An effective organizational structure of the enterprise allows management to accelerate the performance of functions assigned to it. Thus, the effectiveness of the management process allows you to solve problems that arise in the activities of the enterprise quickly. Ensuring the effectiveness of the management process is an effective management structure, which ensures the implementation of management itself as an orderly system of relations between departments and employees of the enterprise. The main purpose of the quality of management of key personnel is to increase the productivity of working time, which will increase the results of the enterprise.

The economic factor of the internal environment is the availability of all financial reserves, borrowed funds and the level of profitability of the enterprise. The level of management efficiency largely depends 
on the skillful management of financial resources. Instead, the environmental factor is expressed in the coverage of eco-destructive impact on the environment, which is in the environmental damage caused, taxes paid, other payments and penalties.

Conclusions. Summarizing the analyzed facts, we can say that all the factors that affect the effectiveness of management decisions are interrelated, and raise a number of pressing issues, the solution of which should be aimed at:

- increasing the level of income of enterprises, both by expanding profits, optimizing production processes and reducing costs for the elimination of eco-destructive effects;

- improving the condition of fixed assets of enterprises;

- increase the adaptability of the enterprise to the influence of environmental factors;

- increasing the financial stability and independence of the enterprise;

- improving the quality of services;

- increasing the level of use of innovations in activities;

- reduction of eco-destructive impact on the environment.

The solution of a number of existing problems of the enterprise is possible at the expense of increase of the efficiency of management. That is why there is an objective need to analyze the current state of efficiency of the enterprise management, as a result of the influence of factors.

\section{REFERENCES:}

1. Soroka R. S. (2003) Faktory vplyvu na zabezpechenistj torghiveljnykh pidpryjemstv oborotnym kapitalom [Factors influencing the provision of trading companies with working capital]. Finance of Ukraine, no. 10, pp. 76-83.

2. Rohanova H. O. (2013) Faktory vplyvu na zabezpechenistj vyrobnycho-torghiveljnykh pidpryjemstv oborotnymy koshtamy [Factors influencing the provision of production and trade enterprises with working capital]. Donbasjka derzhavna mashynobudivna akademija, vol. 2, pp. 1-2. Available at: http://www.rusnauka.com/ 12_KPSN_2013/Economics/10_135036.doc.htm (accessed 21 September 2020).

3. Kulakova S. Yu., Lozovskyi D. M. (2013) Metodologhichni aspekty upravlinnja oborotnymy zasobamy pidpryjemstva [Methodological aspects of working capital management of the enterprise]. Efficient economy, vol. 11, pp.34-37.Availableat:http://www.economy.nayka.com.ual ?op=1\&z=2516 (accessed 21 September 2020).

4. Hordienko N. I. (2009) Finansy pidpryjemstv [Enterprise finances]. Kharkiv: KhNAMGh. (in Ukrainian)

5. Shershnova Z. Ye., Oborska S. V. (1999) Strateghichne upravlinnja [Strategic management]. Kyiv: KNEU. (in Ukrainian)

6. Horielov D. O., Bolshenko S. F. (2010) Strateghija pidpryjemstva [Enterprise strategy]. KhNADU. (in Ukrainian)

7. Minina Ye. O. (2012) Pokaznyky v systemi strateghichnogho upravlinnja zatratamy [Indicators in the system of strategic cost management]. Visnyk socialjnoekonomichnykh doslidzhenj [Bulletin of socio-economic research], vol. 4, no. 47, pp. 224-228.

8. Rumiantseva Z. P. (2001) Zaghaljni osnovy kerivnyctva pidpryjemstvom. Teorija ta praktyka [General basics of enterprise management. Theory and practice]. Moscow: YNFRA-M. (in Ukrainian)

9. Vikhanskiy O. S., Naumov A. I. (2002) Menedzhment [Management]. Moscow: Ghardaryky. (in Ukrainian)

10. Fatkhutdinov R. A., Osovska H. V. (2009) Upravlinnja konkurentospromozhnistju orghanizaciji [Managing the competitiveness of the organization]. Kyiv: Kondor. (in Ukrainian)

11. Huraliuk A. H. (2010) Koncepciji ocinky efektyvnosti upravlinnja navchaljnym zakladom [Concepts of evaluating the effectiveness of school management] Teorija ta metodyka upravlinnja osvitoju, vol. 3, pp. 307-308. Available at: http://tme.umo.edu.ua/docs/3 (accessed 20 September 2020).

12. Lihonenko L. O. (2003) Antykryzove upravlinnja pidpryjemstvom: teoretyko-metodologhichni zasady ta praktychnyj instrumentarij [Anti-crisis management of the enterprise: theoretical and methodological principles and practical tools]. Kyiv: KNTEU. (in Ukrainian)

13. Bielova O. I. (2013) Determinanty motyvacijnogho mekhanizmu strateghichnogho upravlinnja $v$ torghoveljnykh merezhakh: klasyfikacija ta osoblyvosti [Determinants of the motivational mechanism of strategic management in retail chains: classification and features], Innovacijna ekonomika [Innovative economy scientific and production journal], vol. 6, no. 44, pp. 235-241.

14. Shvets Yu. O. (2014) Zovnishni faktory vplyvu na efektyvnistj strateghichnogho upravlinnja oborotnymy koshtamy na pidpryjemstvakh mashynobuduvannja [External factors influencing the effectiveness of strategic management of working capital in machine-building enterprises]. Proceedings of the Problemy ekonomiky ta menedzhmentu: ocinka ta perspektyvy vyrishennja (Ukraine, Lviv, September 26-27, 2014), LEF, vol. 2, pp. 72-75.

15. Trukhan O. L. (2009) Strateghichnyj analiz u systemi upravlinnja pidpryjemstvamy [Strategic analysis in the enterprise management system]. Visnyk ZhDTU [Bulletin of ZhSTU], vol. 1, no. 47, pp. 137-140. Available at: http://eztuir.ztu.edu.ua/2152/1/27.pdf (accessed 18 September 2020).

\section{БІБЛІОГРАФІЧНИЙ СПИСОК:}

1. Сорока Р.С. Фактори впливу на забезпеченість торгівельних підприємств оборотним капіталом. Фінанси України. 2003. № 10. С. 76-83.

2. Роганова Г.О. Фактори впливу на забезпеченість виробничо-торгівельних підприємств оборотними коштами. 2010. С. 1-2. Краматорськ. URL: http://www.rusnauka.com/12_KPSN_2013/Economics/ 10_135036.doc.htm (дата звернення: 21.09.2020).

3. Кулакова С.Ю., Лозовський Д.М. Методологічні аспекти управління оборотними засобами підприємства. Ефрективна економіка. 2013. № 11. URL: http://www.economy.nayka.com.ua/?op=1\&z=2516 (дата звернення: 21.09.2020).

4. Гордієнко Н.І. Фінанси підприємств : конспект лекцій. Харків : ХНАМГ, 2009. С. 115. 
5. Шершньова 3.Є., Оборська С.В. Стратегічне управління : навчальний посібник. Київ : КНЕУ, 1999. С. 384.

6. Горєлов Д.О., Большенко С.Ф. Стратегія підприємства : навчально-методичний посібник. Харків : Видавництво ХНАДУ, 2010. С. 133.

7. Мініна Є.О. Показники в системі стратегічного управління затратами. Вісник соціальноекономічних досліджень. 2012. № 4. С. 224-228.

8. Румянцева 3.П. Загальні основи керівництва підприємством. Теорія та практика : підручник. Москва : ИНФРА-М, 2001. 304 с.

9. Виханський О.С., Наумов А.І. Менеджмент: навчальний посібник. Москва : Гардарики, 2002. 528 с.

10. Фатхутдінов Р.А., Осовська Г.В. Управління конкурентоспроможністю організації : підручник. Київ : Кондор, 2009. 470 с.

11. Гуралюк А.Г. Концепції оцінки ефрективності управління навчальним закладом. Теорія та методика управління освітою. 2010. № 3. С. 307-308. URL: http://tme.umo.edu.ua/docs/3 (дата звернення: 20.09.2020).
12. Лігоненко Л.О. Антикризове управління підприємством: теоретико-методологічні засади та практичний інструментарій. Київ : КНТЕУ, 2001. 580 с.

13. Бєлова O.I. Детермінанти мотиваційного механізму стратегічного управління в торговельних мережах: класифрікація та особливості. Інноваційна економіка. Всеукраїнський науково-виробничий журнал. Серія «Маркетинг в ринкові відносини». 2013. Вип. 6. № 44. С. 235-241.

14. Швець Ю.О. Зовнішні фрактори впливу на ефективність стратегічного управління оборотними коштами на підприємствах машинобудування. Проблеми економіки та менеджменту: оцінка та перспективи вирішення : праці міжнар. наук.-практ. конфр., м. Львів, 26-27 вересня 2014 р. Львів : ЛЕФ, 2014. № 2. C. 72-75.

15. Трухан О.Л. Стратегічний аналіз у системі управління підприємствами. Вісник ЖДТУ. Серія «Економічні наукU». 2009. Вип. 1. № 47. С. 137-140. URL: http://eztuir.ztu.edu.ua/2152/1/27.pdf (дата звернення: 18.09.2020). 